\title{
Determination of M ethyl Mercury by Aqueous Phase Ethylation, Follow ed by Gas Chromatographic Separation with Cold Vapor Atomic Fluorescence Detection
}

Open-File Report 01- 445
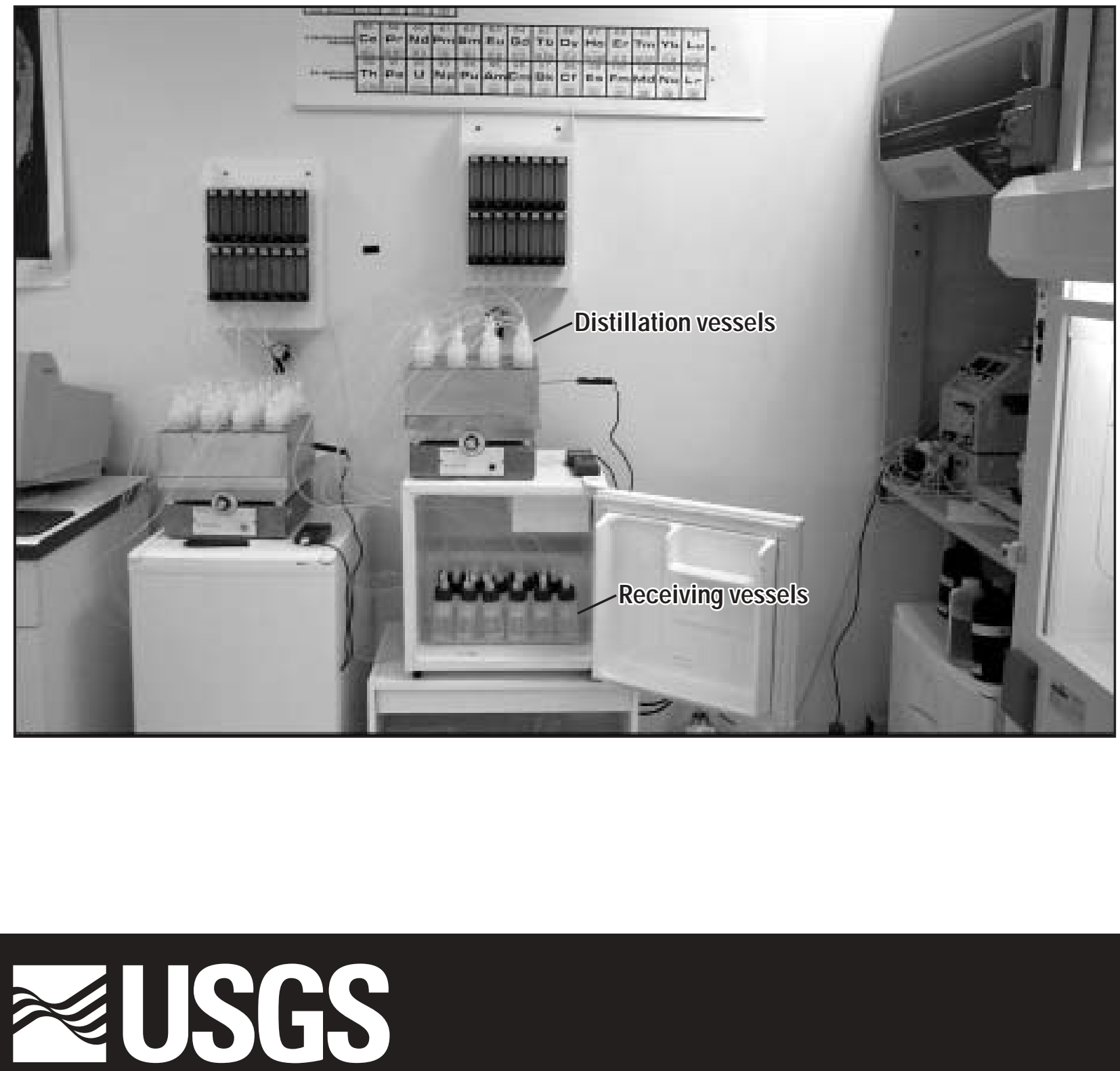
Determination of Methyl Mercury by Aqueous Phase Ethylation, Followed by Gas Chromatographic Separation with Cold Vapor Atomic Fluorescence Detection

By John F. De Wild, Mark L. Olson, and Shane D. Olund

U.S. GEOLOGICAL SURVEY

Open-File Report 01-445

Middleton, Wisconsin

2002

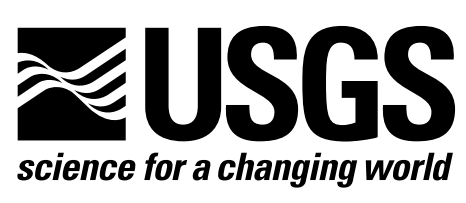




\title{
U.S. DEPARTMENT OF THE INTERIOR \\ Gale A. Norton, Secretary
}

\author{
U.S. GEOLOGICAL SURVEY \\ Charles G. Groat, Director
}

The use of firm, trade, and brand names in this report is for identification purposes only and does not constitute endorsement by the U.S. Government.

District Chief

U.S. Geological Survey

8505 Research Way

Middleton, WI 53562-3586
U.S. Geological Survey

Branch of Information Services

Box 25286

Denver, CO 80225-0286 


\section{CONTENTS}

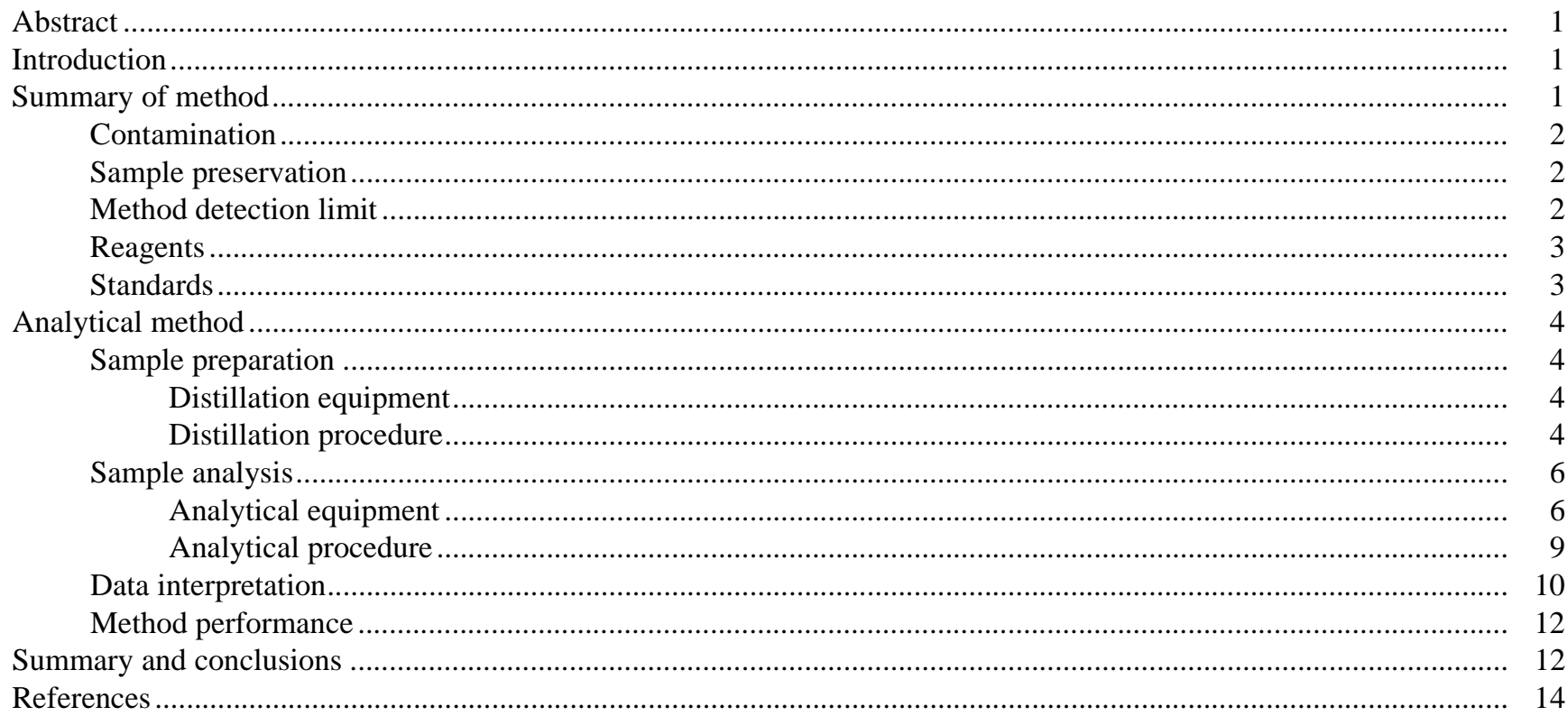

\section{FIGURES}

1-3. Photographs showing:

1. Methyl mercury distillation system. (A) entire system, (B) distillation block, (C) distillation vessel cap, and (D) receiving vessel cap

2. Methyl mercury reaction and purging system. (A) entire system, (B) sparging stopper fitted with a four-way valve, (C) reaction vessel in the closed (reaction) position, and (D) reaction vessel; in the open (purging) position

3. Methyl mercury desorbtion and detection system. (A) entire system, (B) sample trap, (C) gas chromatographic column, and (D) pyrolytic column

4. Graph showing example of methyl mercury detection chromatograph with peak identities

\section{TABLES}

1. Results from multiple analyses of surface water and ground water for detection limit assay ................................ 2

2a. Results for the analysis of ground water spiked at two different concentrations .................................................. 12

2b. Results for the analysis of spiked and unspiked Canada surface water .............................................................. 13

2c. Results for the analysis of spiked and unspiked Everglades' surface water .......................................................... 13 


\title{
ABBREVIATED WATER-QUALITY UNITS
}

\begin{abstract}
Abbreviated water-quality units used in this report: Chemical concentration is given in milligrams per liter (mg/L), micrograms per liter $(\mu \mathrm{g} / \mathrm{L})$ or nanograms per liter $(\mathrm{ng} / \mathrm{L})$. Milligrams per liter is a unit expressing the concentration of chemical constituents in solution as weight (milligrams) of solute per unit volume (liter) of water. One thousand micrograms per liter is equivalent to one milligram per liter. One thousand nanograms per liter is equal to one microgram per liter.
\end{abstract}

Temperature in degrees Celsius $\left({ }^{\circ} \mathrm{C}\right)$ can be converted to degrees Fahrenheit $\left({ }^{\circ} \mathrm{F}\right)$ by use of the following equation:

$$
{ }^{\circ} \mathrm{F}=1.8\left({ }^{\circ} \mathrm{C}\right)+32 .
$$

\section{Other Abbreviations Used in this Report:}

$\begin{array}{ll}\mathrm{ng} / \mathrm{L} & \text { nanograms per liter (parts per trillion) } \\ \mathrm{ng} / \mathrm{mL} & \text { nanograms per milliliter (parts per billion) } \\ \mathrm{mg} / \mathrm{L} & \text { milligrams per liter } \\ \mu \mathrm{g} / \mathrm{g} & \text { micrograms per gram (parts per million) } \\ \mathrm{g} & \text { gram } \\ \mathrm{mg} & \text { milligram }\left(10^{-3} \text { grams }\right) \\ \mu \mathrm{g} & \text { microgram }\left(10^{-6} \text { grams }\right) \\ \mathrm{ng} & \text { nanograms }\left(10^{-9} \text { grams }\right) \\ \mathrm{pg} & \text { picogram }\left(10^{-12} \text { grams }\right) \\ \mathrm{N} & \text { normality }(\text { the number of equivalents per liter of solution) } \\ \mathrm{M} & \text { molarity (the number of moles of solute per liter of solution) } \\ \mathrm{M} \Omega & \text { microMohs } \\ \mathrm{cm} & \text { centimeters }\left(10^{-2} \text { meters }\right) \\ \mathrm{mm} & \text { millimeters }\left(10^{-3} \text { meters }\right) \\ \mu \mathrm{M} & \text { micron }\left(10^{-3} \text { millimeters) }\right. \\ \mathrm{L} & \text { liters } \\ \mathrm{mL} & \text { milliliters }\left(10^{-3} \text { liters }\right) \\ \mu \mathrm{L} & \text { microliters }\left(10^{-6} \text { liters }\right) \\ \mathrm{mL} / \mathrm{min} & \text { milliliters per minute } \\ \mathrm{in} & \text { inches }\end{array}$




\title{
Determination of Methyl Mercury by Aqueous Phase Ethylation, Followed by Gas Chromatographic Separation with Cold Vapor Atomic Fluorescence Detection
}

\author{
by John F. De Wild, Mark L. Olson, and Shane D. Olund
}

\section{Abstract}

A recent national sampling of streams in the United States revealed low methyl mercury concentrations in surface waters. The resulting median and mean concentrations, calculated from 104 samples, were 0.06 nanograms per liter (ng/L) and $0.15 \mathrm{ng} / \mathrm{L}$, respectively. This level of methyl mercury in surface water in the United States has created a need for analytical techniques capable of detecting sub-nanogram per liter concentrations. In an attempt to create a U.S. Geological Survey approved method, the Wisconsin District Mercury Laboratory has adapted a distillation/ethylation/gas-phase separation method with cold vapor atomic fluorescence spectroscopy detection for the determination of methyl mercury in filtered and unfiltered waters. This method is described in this report. Based on multiple analyses of surfacewater and ground-water samples, a method detection limit of $0.04 \mathrm{ng} / \mathrm{L}$ was established. Precision and accuracy were evaluated for the method using both spiked and unspiked ground-water and surface-water samples. The percent relative standard deviations ranged from 10.2 to 15.6 for all analyses at all concentrations. Average recoveries obtained for the spiked matrices ranged from 88.8 to 117 percent. The precision and accuracy ranges are within the acceptable method-performance limits. Considering the demonstrated detection limit, precision, and accuracy, the method is an effective means to quantify methyl mercury in waters at or below environmentally relevant concentrations.

\section{INTRODUCTION}

Presently (2002), 41 States in the Nation have issued fish consumption advisories because of the high levels of mercury $(\mathrm{Hg})$ in fish (U.S. Environmental Protection Agency, 2001a). Over the past 15 years, scientists have revealed that methyl mercury $\left(\mathrm{CH}_{3} \mathrm{Hg}^{+}\right)$is the specific form of mercury that bioaccumulates most readily in mammals (Bloom, 1992), is the most toxic, and where research priorities are needed to better understand and respond appropriately to this widespread contamination problem. Within the U.S. Geological Survey (USGS), the importance of $\mathrm{Hg}$ as a contaminant is demonstrated in that it has been selected as one of five priority issues to be addressed over the next 10 years as part of the National Water-Quality Assessment (NAWQA) program. Because of the increased awareness of environmental $\mathrm{Hg}$ contamination, and the understanding that the production and bioaccumulation of $\mathrm{CH}_{3} \mathrm{Hg}^{+}$drives the contamination problem, the need for a reliable analytical method for $\mathrm{CH}_{3} \mathrm{Hg}^{+}$has increased. Horvat and others (1993) were the first to describe a distillation/ethylation/gas-phase separation method for $\mathrm{CH}_{3} \mathrm{Hg}^{+}$, which greatly reduces matrix-interference problems, and that largely has been adopted worldwide by $\mathrm{Hg}$ research laboratories. Since the start up of the USGS Wisconsin District Mercury Laboratory (WDML) in 1995, an adaptation of this method has been the operational method for $\mathrm{CH}_{3} \mathrm{Hg}^{+}$determinations. The purpose of this report is to document the method and describe the results of a methodological test of the WDML's ability to provide quality data at $\mathrm{ng} / \mathrm{L}$ concentrations for $\mathrm{CH}_{3} \mathrm{Hg}^{+}$in water samples.

\section{SUMMARY OF METHOD}

Water samples are distilled to remove potential matrix interferences. The $\mathrm{pH}$ of the distillate is adjusted to 4.9 (to maximize ethylation potential) using acetate 
buffer. The distillate then is ethylated using sodium tetraethyl borate $\left(\mathrm{NaBEt}_{4}\right)$ and allowed to react for 15 minutes. After reaction with $\mathrm{NaBEt}_{4}$, the distillate is purged with nitrogen gas $\left(\mathrm{N}_{2}\right)$ for 20 minutes and the ethylated mercury species are collected on a sample trap containing Carbotrap. These ethylated mercury species are desorbed thermally from the sample trap, separated using a gas chromatographic (GC) column, reduced using a pyrolytic column, and detected using a cold vapor atomic fluorescence spectrometry (CVAFS) detector.

This method may be used to determine $\mathrm{CH}_{3} \mathrm{Hg}^{+}$ concentrations in filtered or unfiltered water samples in the range of $0.040-5 \mathrm{ng} / \mathrm{L}$. The upper range may be extended to higher concentrations by distilling smaller sample volumes or ethylating less of the distillate.

It should be noted that repeated attempts to analyze reagent grade water spiked with $\mathrm{CH}_{3} \mathrm{Hg}^{+}$resulted in low recoveries (40-60 percent). The reasons for these low recoveries have not been resolved; however, other mercury research laboratories also obtain similar recov= eries (J. Hurley, University of Wisconsin; C. Gilmour, Academy of Natural Sciences, oral commun., 2001). Therefore, reagent water is not an appropriate water source for spiked standard solutions and should not be used for quality-assurance or quality=control purposes.

\section{Contamination}

Methyl mercury analysis, as with all trace metal analysis, is extremely sensitive to contamination. Extreme care must be taken to avoid contamination in the collection and analysis steps of this method. All of the sample collection and analytical equipment that comes in contact with samples must be Teflon or glass and vigorously cleaned prior to and between uses. New Teflon equipment is rinsed with tap water, and cleaned by immersing in a $4 \mathrm{~N}$ hydrochloric acid $(\mathrm{HCl})$ bath heated to $65^{\circ} \mathrm{C}$ for at least 48 hours. Immediately following removal from the bath, the equipment is immersed in fresh reagent grade water and rinsed at least three times with reagent grade water. Following the rinsing step, each sample bottle is filled to 25 percent full volume with $0.12 \mathrm{~N} \mathrm{HCl}$ and capped. The exte= rior of the bottles and all other equipment is allowed to air dry on a $\mathrm{Hg}$-clean bench under a laminar flow hood equipped with a High Efficiency Particulate Air

(HEPA) filter which is 99.99 percent efficient on particles less than 0.3 microns in diameter. Dry equipment is double bagged in new zip-type bags. After the initial
48 hour cleaning, equipment needs to be immersed in the hot acid for only 24 hours.

\section{Sample Preservation}

Samples are acidified with $6 \mathrm{~N} \mathrm{HCl}$ to 1 percent, volume to volume (v/v), and kept in the dark to prevent photodegradation (Krabbenhoft and others, 2001) of $\mathrm{CH}_{3} \mathrm{Hg}^{+}$. Samples preserved in this manner can be held for up to 6 months before analysis (Bloom, 1995).

\section{Method Detection Limit}

The U.S. Environmental Protection Agency (USEPA) has established a fish tissue methyl mercury enforcement standard of $0.3 \mu \mathrm{g} / \mathrm{g}$ (U.S. Environmental Protection Agency, 2001b). A water column concentra= tion of $0.058 \mathrm{ng} / \mathrm{L}$ was determined to correspond with a $0.3 \mu \mathrm{g} / \mathrm{g}$ fillet concentration for age-3 largemouth bass (Brumbaugh and others, 2001). To demonstrate that the WDML can accurately quantify methyl mercury in water samples at or below this environmentally impor= tant level, a method detection limit study was performed. A method detection limit of $0.04 \mathrm{ng} / \mathrm{L}$ was determined from multiple analyses of an unspiked surface-water sample and a spiked ground-water sample (table 1) according to USEPA protocol (U.S. Environmental Protection Agency, 1990). The ground-water sample was collected from a residential well in a $1 \mathrm{~L}$ Teflon bottle; $0.1 \mathrm{ng}$ of $\mathrm{CH}_{3} \mathrm{Hg}^{+}$standard was added to the sample at the lab and the sample was then acidified with $12 \mathrm{~N} \mathrm{HCl}$ to 1 percent (v/v). Each of these samples was distilled in seven separate distillation batches and analyzed over five days.

Table 1. Results from multiple analyses of surface water and ground water for detection limit assay

[All concentrations in nanograms per liter (ng/L)]

\begin{tabular}{lcc}
\hline & $\begin{array}{c}\text { Unspiked } \\
\text { surface water }\end{array}$ & $\begin{array}{c}\text { Spiked } \\
\text { ground water }\end{array}$ \\
\hline & 0.134 & 0.093 \\
& .095 & .078 \\
& .123 & .095 \\
& .102 & .090 \\
& .101 & .064 \\
& .116 & .090 \\
& .115 & .099 \\
Average & .095 & .085 \\
Standard deviation & .110 & .087 \\
Percent relative & .014 & .011 \\
standard deviation & & .033 \\
Detection limit & 12.9 & \\
$\quad$ (standard deviation x 2.998) & .042 & \\
\hline
\end{tabular}




\section{Reagents}

All reagents and/or dry chemicals used to make reagents must be of high purity and low in $\mathrm{Hg}$.

A. Reagent water: Ultra pure reagent grade water shown to be greater than $18 \mathrm{M} \Omega$ starting from a pre-purified source (distilled, RO, and others) and found to be less than $0.1 \mathrm{ng} / \mathrm{L} \mathrm{Hg}$. The water is delivered through a $0.2 \mu \mathrm{M}$ filter, as obtained from a Millipore Academic water-purification system or equivalent.

B. Copper sulfate: $1 \mathrm{M} \mathrm{CuSO}_{4}$ in reagent water.

C. Hydrochloric acid: Concentrated $\mathrm{HCl}$ found to be less than $0.5 \mathrm{ng} / \mathrm{L} \mathrm{Hg}$ (EM Science Omni Trace or equivalent).

D. Acetate buffer: $11.8 \mathrm{~mL}$ of glacial acetic acid and $27.2 \mathrm{~g}$ reagent grade sodium acetate trihydrate diluted to $100 \mathrm{~mL}$ with reagent water.

E. Ethylating Reagent: $1 \mathrm{~g}$ of Sodium Tetraethyl Borate ( $\mathrm{NaBEt}_{4}$; Strem 11-0575) dissolved in $100 \mathrm{~mL}$ of 2 percent Potassium Hydroxide $(\mathrm{KOH})$, weight to weight (w/w), solution that has been chilled to form slush. $\mathrm{The} \mathrm{NaBEt}_{4}$ solution is divided equally among 9 clean $15 \mathrm{~mL}$ Teflon vials that then are capped and frozen. This solution should be kept frozen and made fresh every 2 weeks. Never use $\mathrm{NaBEt}_{4}$ solid or solutions that are yellow in color. Note: NaBEt 4 is toxic, gives off toxic gases (triethylboron) and is spontaneously combustible. Any NaBEt 4 use should take place in a high-volume fume hood. To discard unused portions of ethylating reagent, empty bottles into a large beaker of $6 \mathrm{~N}$ hydrochloric acid $(\mathrm{HCl})$ inside a high-volume fume hood. Place beaker on a hotplate and boil down to half-volume, then discard the remaining solution as an acid waste. Triethylboron will boil off into the air where it is oxidized to harmless boric acid.

F. Nitrogen $\left(\mathrm{N}_{2}\right)$. Ultra high purity grade $5.0 \mathrm{~N}_{2}$ passed through a gold bead trap attached to the outlet of the tank to remove any $\mathrm{Hg}$.

G. Argon (Ar). Ultra high purity grade 5.0 Ar passed through a gold bead trap attached to the outlet of the tank to remove any $\mathrm{Hg}$.

\section{Standards}

Upon receipt at the laboratory or on the day of preparation, reagent containers should be labeled with the date received or made and the initials of the person preparing them. The stock and substock standards should be stored outside of the $\mathrm{Hg}$-clean analytical laboratory to prevent contamination of the laboratory.

A. $\mathrm{CH}_{3} \mathrm{Hg}^{+}$stock solution $\left(1,000 \mathrm{mg} / \mathrm{L} \mathrm{CH}_{3} \mathrm{Hg}^{+}\right.$as $\mathrm{Hg}$ ): $1.252 \mathrm{~g}$ of reagent grade methyl $\mathrm{Hg}$ chloride (Strem $80-2250$ ) is dissolved in $1 \mathrm{~L}$ of 2 percent glacial acetic acid, 0.2 percent $\mathrm{HCl} \mathrm{v} / \mathrm{v}$.

B. $\mathrm{CH}_{3} \mathrm{Hg}^{+}$substock solution $\left(1 \mathrm{mg} / \mathrm{L} \mathrm{CH}_{3} \mathrm{Hg}^{+}\right.$as $\mathrm{Hg}$ ): Dilute $100 \mu \mathrm{L}$ of $\mathrm{CH}_{3} \mathrm{Hg}^{+}$stock solution to $100 \mathrm{~mL}$ with 2 percent glacial acetic acid, 0.2 percent $\mathrm{HCl}$ v/v.

C. $\mathrm{CH}_{3} \mathrm{Hg}^{+}$working standard $\left(1 \mathrm{ng} / \mathrm{mL} \mathrm{CH}_{3} \mathrm{Hg}^{+}\right.$as $\left.\mathrm{Hg}\right)$ : Dilute $100 \mu \mathrm{L}$ of $\mathrm{CH}_{3} \mathrm{Hg}^{+}$substock solution to 100 $\mathrm{mL}$ with 2 percent glacial acetic acid, 0.2 percent $\mathrm{HCl} \mathrm{v/v.} \mathrm{Because} \mathrm{measurement} \mathrm{errors} \mathrm{are} \mathrm{present} \mathrm{in} \mathrm{lab-}$ oratory processes the exact concentration of the working standard must be determined analytically. The following procedure is used to determine the exact concentration of the working standard.

1. Add $8.0 \mathrm{~mL}$ of reagent grade water; $1.0 \mathrm{~mL}$ of the $\mathrm{CH}_{3} \mathrm{Hg}^{+}$working standard and $1.0 \mathrm{~mL}$ of bromine monochloride $(\mathrm{BrCl})$ to four $15 \mathrm{~mL}$ Teflon vials.

2. Add $9.0 \mathrm{~mL}$ of reagent grade water and $1.0 \mathrm{~mL}$ of $\mathrm{BrCl}$ to four $15 \mathrm{~mL}$ Teflon vials.

3. Double bag and place the eight vials described in steps 1 and 2 into an oven at $50^{\circ} \mathrm{C}$ overnight and analyze each aliquot for total $\mathrm{Hg}$ by USEPA method 1631.

4. Analyze four separate $1.0 \mathrm{~mL}$ aliquots of the $\mathrm{CH}_{3} \mathrm{Hg}^{+}$working standard for inorganic $\mathrm{Hg}(\mathrm{Hg}(\mathrm{II})$; readily reducible with $\mathrm{SnCl}_{2}$ ) using USEPA method 1631 without the $\mathrm{BrCl}$ oxidation step.

5. Subtract the average blank concentration determined from analyses of solutions in step 2 from the average concentration determined from analyses of the solutions in step 1 to determine the reagent blank corrected concentration of the working standard. 
6. Subtract the average concentration of the $\mathrm{Hg}(\mathrm{II})$ in the $\mathrm{CH}_{3} \mathrm{Hg}^{+}$working standard, determined in step 4 , from the reagent blank corrected value determined in step 5 to determine the actual working-standard concentration.

\section{ANALYTICAL METHOD}

\section{Sample Preparation}

Samples must be distilled prior to analysis to remove potential matrix interferences such as reduced sulfur containing compounds, calcium, and humic acids associated with dissolved organic carbon (Horvat and others, 1993).

\section{Distillation Equipment}

The distillation system (fig. 1a) consists of a solid aluminum heating block, a small refrigerator, Teflon distillation and receiving vessels, and Teflon transfer lines.

A. A custom fabricated aluminum block (fig. 1b) is heated with a Thermolyne type 2200 (or equivalent) hot plate during the distillation step. A temperature probe placed in the center of the block monitors block temperature.

B. A small commercially available refrigerator is used to hold the receiving vials, aid in condensation, maintain distillate at $4{ }^{\circ} \mathrm{C}$ and protect the distillate from exposure to light. Small holes are drilled in the side of the refrigerator to accommodate the transfer lines.

C. The distillation and receiving vessels are $125 \mathrm{~mL}$ Teflon bottles (Nalgene catalogue number 1630-0004 or equivalent). The distillation vessel caps (fig. 1c) and receiving vessel caps (fig. 1d) consists of a Teflon insert (Savillex part number 0738-4-2 or equivalent) molded integrally with two transfer ports equipped with compression fittings for 1/4-in. (6.4 mm) outside diameter (O.D.) tubing. A length of 1/4-in. O.D. tubing is inserted into one of the ports so that it will extend to within $2 \mathrm{~mm}$ of the bottom of the distillation and receiving vessels to insure complete sample purging and recondensation, respectively. A short length of 1/4-in. O.D. tubing also must be inserted flush with the lower side of the insert in the remaining port to accommodate the transfer line. The Teflon bottle caps must be machined to accommodate the insert and form an airtight seal for the distillation vessels, whereas the green polypropylene cap included with the insert can be used for the receiving vessels. Teflon transfer lines of 1/8-in. (3.2 mm) O.D. are connected by friction fit from the outlet tubing of the distillation vessel to the inlet tubing of the receiving vessel.

D. Flowmeters capable of maintaining a flow of $60 \mathrm{~mL} / \mathrm{min}$ of $\mathrm{N}_{2}$ are placed immediately upstream of the distillation vials to maintain constant and equal flow to all distillation vials. Gas is supplied through 1/8-in.

O.D. Teflon line inserted into the inlet tubing of the distillation vessel.

\section{Distillation Procedure}

A WDML distillation batch consists of 11 environmental samples, 3 method blanks, a matrix spike, and a matrix spike duplicate. Distillation blanks are reagent grade water acidified with $12 \mathrm{~N} \mathrm{HCl}$ to 1 percent (v/v). The matrix spike and matrix-spike duplicates are prepared by adding a known amount of working standard to two of three bottles containing similar volumes of the same sample.

A. Dispense approximately $60 \mathrm{~mL}$ of water (sample or reagent water) into each distillation vessel and add $1 \mathrm{~mL}$ of $1 \mathrm{M} \mathrm{CuSO}_{4}$ (to bind sulfide-Olson and others, 1997) to each of the bottles in the batch. Record the bottle identifier, tare weight and full weight of each vessel. Cap each of the vials with the distillation cap corresponding to the block position to be occupied by that vial.

B. Dispense approximately $40 \mathrm{~mL}$ of reagent water to each of the receiving vessels. Record the bottle identifier, tare weight and bottle plus reagent water weight of each. Cap each of the vials with the receiving cap corresponding to the block position occupied by the matching distillation vessel. 

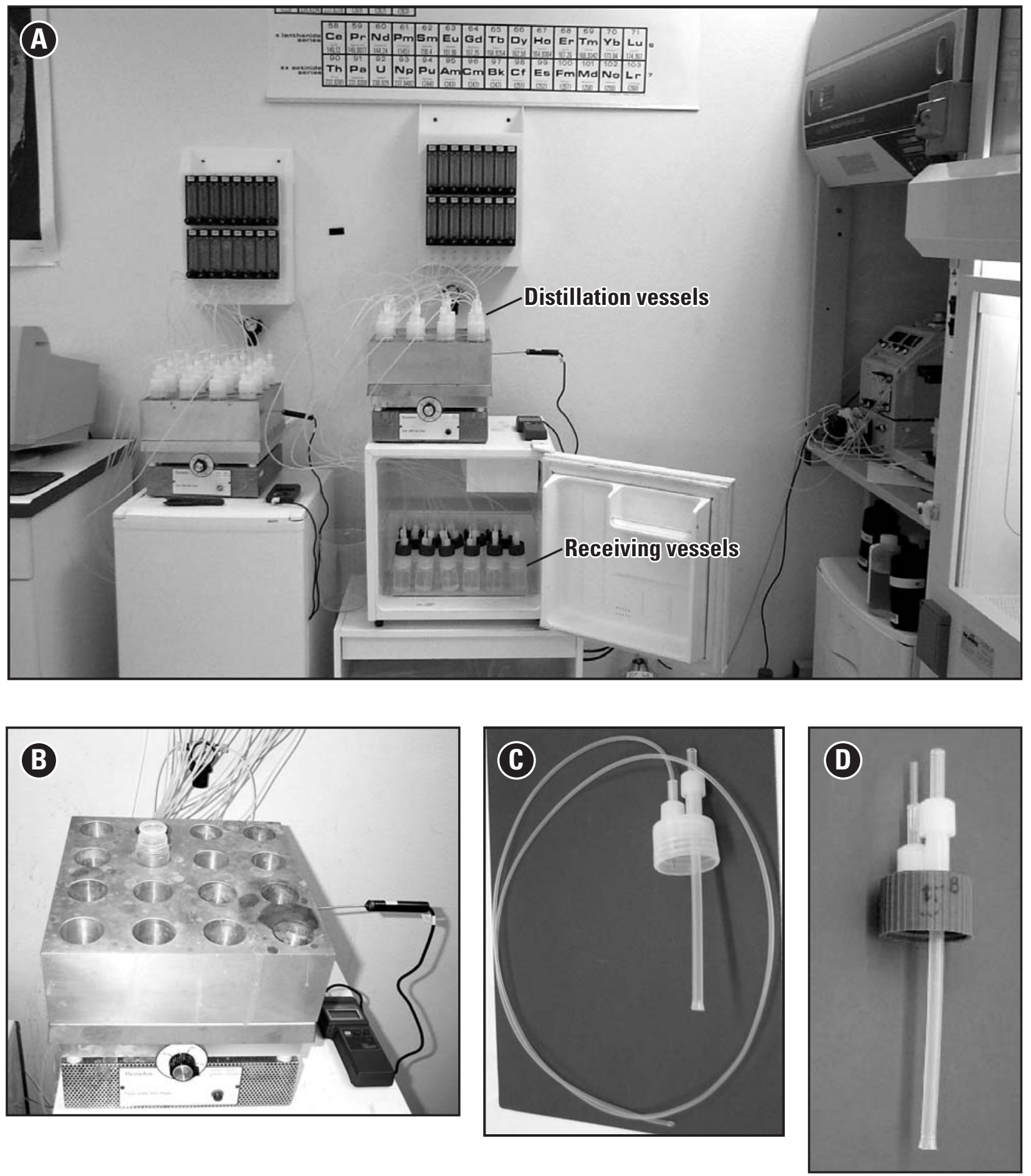

Figure 1. Methyl mercury distillation system: $(A)$ entire system, $(B)$ distillation, $(C)$ distillation vessel cap, and (D) receiving vessel cap. 
C. Place the distillation vials in their respective positions in the distillation block and thread the transfer lines through the numbered holes in the refrigerator.

D. Turn on the $\mathrm{N}_{2}$ flow to the flowmeters and connect the gas lines to the inlet ports of the distillation caps.

E. Place the receiving vial tray in the refrigerator and begin placing the receiving vials into the tray. As the receiving vials are placed into the tray, connect the transfer lines to the inlet ports of the receiving caps. Check for bubbling in the reagent water. This checking verifies a leak-free system.

F. Adjust the flow on the flowmeters to $60 \mathrm{~mL} / \mathrm{min}$. Adjust the hot plate temperature to maintain a block temperature of $120+/-5^{\circ} \mathrm{C}$. This temperature should result in a distillation rate of $6-8 \mathrm{~mL}$ per hour but adjustments may need to be made for individual systems.

G. Check the receiving vials to ensure unrestricted flow, the distillation vials to ensure no leakage, and the block temperature for stability periodically throughout the distillation.

H. Remove the transfer lines from the receiving vessels and the distillation vessels from the block when approximately 20 percent of the volume in the distillation vessel remains. The distillation caps as well as the inside of the transfer lines should be rinsed thoroughly with reagent water.

I. Weigh the receiving vessels and record the weight for later determination of the percent of the original sample that was distilled. Cap the bottles and place in a refrigerator at $4^{\circ} \mathrm{C}$ until analysis (distillates should be analyzed within 48 hours).

\section{Sample Analysis}

After the samples have been distilled, they are ready for analysis and should be analyzed within 48 hours. The analysis is a two-step process consisting of purging the mercury species from the distillate and detecting the mercury species with a cold vapor atomic fluorescence detector.

\section{Analytical Equipment}

The analytical portion of the process requires two separate systems; one for loading the traps (fig. 2a) and one for desorbing and detecting the $\mathrm{Hg}$ species (fig. 3a). The anlalytical equipement used is listed below.

A. Flow meters equipped with needle valves capable of delivering a $\mathrm{N}_{2}$ flow of $250 \mathrm{~mL} / \mathrm{min}$ to the reaction vessels.

B. Reaction vessels (figs. $2 \mathrm{c}$ and $2 \mathrm{~d}$ ) are $250 \mathrm{~mL}$ Erlenmeyer flask with a standard/taper 24/40 neck and a sparging stopper fitted with a four-way valve (fig. 2b).

C. Sample traps (fig. 3b) are made from $7 \mathrm{~mm}$ quartz tubes, $10 \mathrm{~cm}$ long with a constriction at $3 \mathrm{~cm}$ from the

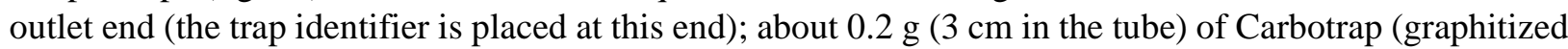
carbon black, Supelco 2-0287 or equivalent) is placed in the center and contained by quartz wool plugs at either end. Small pieces of $7 \mathrm{~mm}$ Teflon tubing are friction fit to the ends of the sample traps to provide a connection point between the sample trap and the reaction vessel, and to provide connection points in the analytical train.

D. An analytical balance capable of measuring to the nearest $0.1 \mathrm{~g}$ is used to determine sample volumes to the nearest $0.1 \mathrm{~mL}$.

E. Pneumatic fixed-volume and variable pipettes ranging from $5 \mu \mathrm{L}$ to $5 \mathrm{~mL}$.

F. Hewlett Packard model HP3395 integrator or equivalent, connected to a timer, controls the analytical system. The timer is connected to a transformer that is connected to a Nichrome wire coil wrapped to fit around the sample trap.

G. The gas chromatographic column (fig. 3c) is a $4 \mathrm{~mm}$ inside diameter (I.D.), $6 \mathrm{~mm}$ O.D., glass column $50 \mathrm{~cm}$ long and filled with Chromosorb WAW-DMSC 60/80 mesh (Supelco 2-0152) enclosed in a glass sheath $2 \mathrm{~cm}$ in diameter and $25 \mathrm{~cm}$ long. This column is housed in a cylindrical oven (figs. $3 \mathrm{a}$ and $3 \mathrm{c}$ ) connected to a transformer, which supplies a constant voltage to maintain a temperature of $95+/-5^{\circ} \mathrm{C}$. Column 

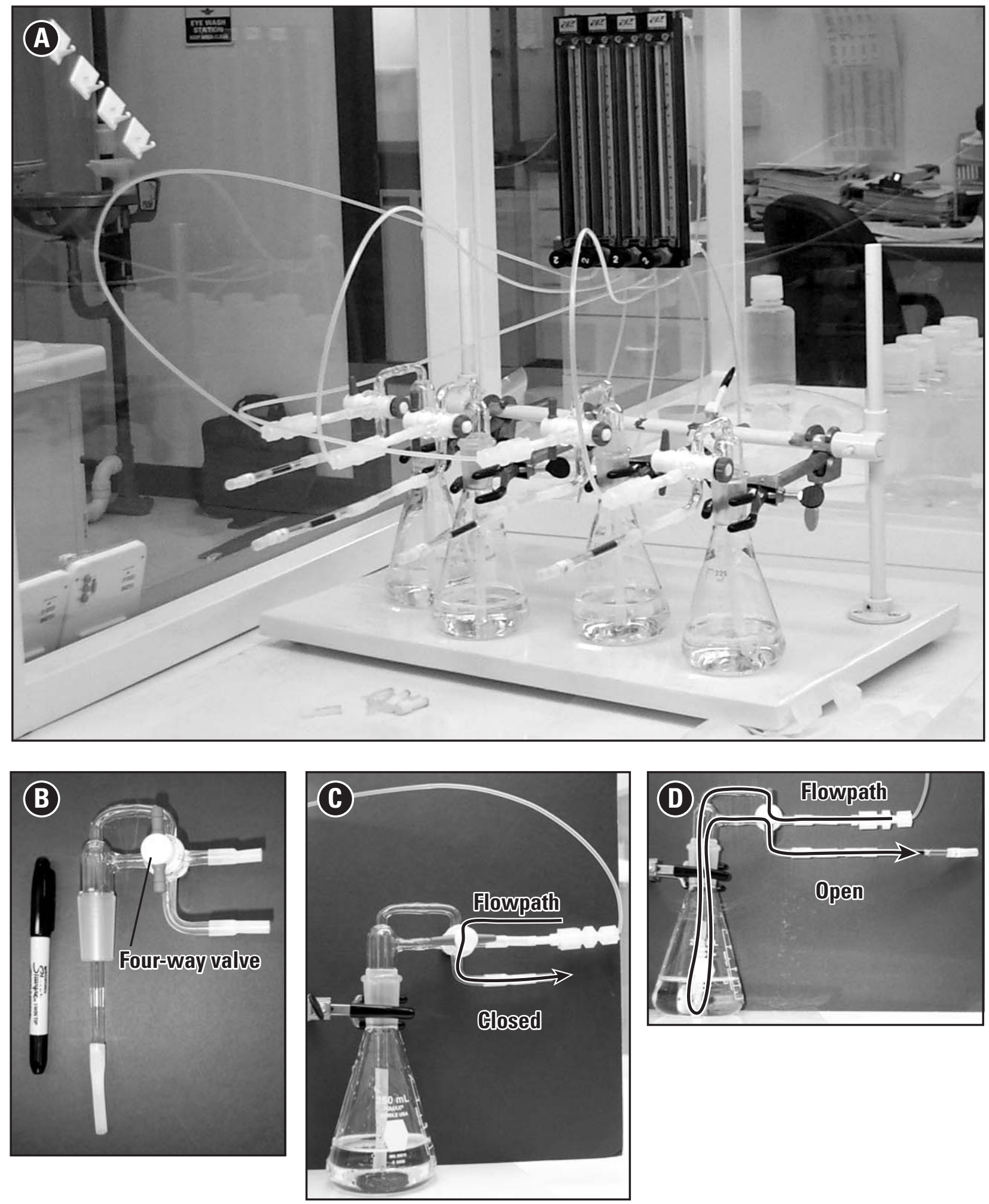

Figure 2. Methyl mercury reaction and purging system: (A) entire system, (B) sparging stopper fitted with a four-way valve, (C) reaction vessel in the closed (reaction) position, and (D) reaction vessel in the open (purging) position. 

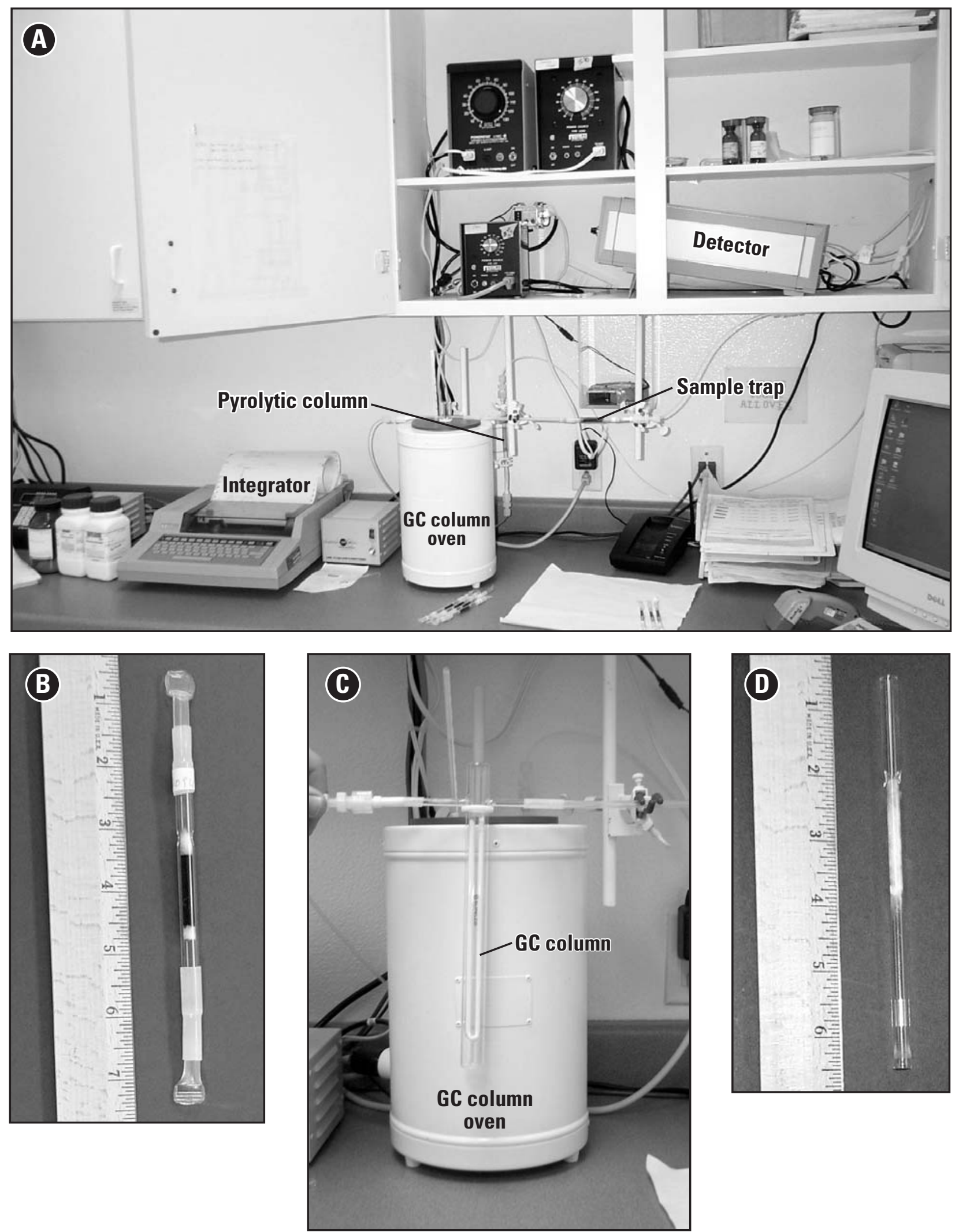

Figure 3. Methyl mercury desorbtion and dectection system: (A) entire system, (B) sample trap, (C) gas chromatographic column, and (D) pyrolytic column. 
oven temperature may need to be adjusted on individual systems to insure good peak separation and symmetry.

H. The pyrolytic column (fig. $3 \mathrm{~d}$ ) is a $7 \mathrm{~mm}$ quartz tube $15 \mathrm{~cm}$ in length with the center $4-5 \mathrm{~cm}$ filled with quartz wool. Small pieces of $7 \mathrm{~mm}$ Teflon tubing are friction fit to the ends of the pyrolytic column to provide connection points in the analytical train. A length of nichrome wire is wrapped around the tube to cover the length of quartz wool. The wire is connected to a transformer that heats the column to approximately $800^{\circ} \mathrm{C}$.

I. The detector is a commercially available Model 2500 CVAFS Mercury Detector from Tekran (Toronto, Ontario) equipped with a mass flow controller capable of maintaining $20 \mathrm{~mL} / \mathrm{min}$ of Argon flow through the entire analytical train. Detector analog output returns to the HP3395 integrator where the peak areas are recorded.

\section{Analytical Procedure}

A WDML analytical batch generally consists of 2 distillation batches, as well as standards and blanks used to evaluate the performance of the analytical train. All chemical additions to the reaction vessels are carried out in a fume hood and then the vessels are transferred to a clean bench below a laminar flow hood equipped with a HEPA filter which is 99.99 percent efficient on particles less than 0.3 microns in diameter.

A. Create a standard curve by adding varying amounts of working standard (typically $100,50,25$, and $10 \mu \mathrm{L}$, but the range needs to cover the expected concentrations in the analytical batch) to approximately $100 \mathrm{~mL}$ of reagent water in each of the reaction vessels. Pipette $200 \mu \mathrm{L}$ of acetate buffer and $100 \mu \mathrm{L}$ of $\mathrm{NaBEt}_{4}$ to each of the reaction vessels. The $\mathrm{NaBEt}_{4}$ reagent serves to derivatize the two remaining ionic $\mathrm{Hg}$ species after the distillation step (inorganic $\mathrm{Hg}$ (II) and $\mathrm{CH}_{3} \mathrm{Hg}^{+}$) to their ethylated forms (diethyl $\mathrm{Hg}$ and methylethyl $\mathrm{Hg}$, respectively). Elemental $\mathrm{Hg}$ does not react with the $\mathrm{NaBEt}_{4}$. Note: The NaBEt needs $_{\text {no remain }}$ near $0^{\circ} \mathrm{C}$. It should be removed from the freezer approximately 3 minutes before being added to the reaction vessels and placed in a dark place to partially thaw. A new vial of $\mathrm{NaBEt}_{4}$ should be used each day.

B. Tighten the sparging stoppers, ensure the four-way valve is in the closed position (fig. 2c), gently swirl the reaction vessels, and allow the reaction to proceed for 15 minutes. After the reaction time has elapsed, remove the plugs from the ends of the sample traps. Place the sample traps onto the outlet of the reaction vessels, with the identification number downstream, turn the four-way valve to the open position (fig. 2d), and allow grade $5 \mathrm{~N}_{2}$ to purge the vessel at a rate of $250 \mathrm{~mL} / \mathrm{min}$ for 20 minutes.

C. After the samples have been purged, turn the four-way valve to the closed position and remove the sample trap from the reaction vessel outlet. Remove the $\mathrm{N}_{2}$ line from the inlet of the four-way valve and place the sample trap on the end of the $\mathrm{N}_{2}$ line. Allow the $\mathrm{N}_{2}$ to flow through the sample traps at $250 \mathrm{~mL} / \mathrm{min}$ for 7 minutes to remove any water vapor that has collected on the sample trap.

D. Four ethylation blanks are prepared by adding approximately $100 \mathrm{~mL}$ of reagent grade water, $200 \mu \mathrm{L}$ of acetate buffer, and $100 \mu \mathrm{L}$ of $\mathrm{NaBEt}_{4}$ to separate reaction vessels. Then proceed as in step B.

E. While one set of reaction vessels and sample traps are being used to collect the purged sample, the other set can be desorbed and analyzed. Remove the sample traps from the $\mathrm{N}_{2}$ lines, attach the $\mathrm{N}_{2}$ lines to the inlets of the four-way valves, and cap both ends of the sample traps.

F. To desorb and analyze the traps, remove the plugs from the ends of the first trap and place it into the analytical train (fig. 3a) by threading it, with the identification number upstream, through the center of the nichrome wire coil. Center the nichrome wire over the Carbotrap, allow the flow to stabilize for approximately $30 \mathrm{sec}-$ onds, and press start on the integrator. The nichrome wire will heat to $250^{\circ} \mathrm{C}$ with a ramp time of 30 seconds to desorb the $\mathrm{Hg}$ from the sample trap. As the $\mathrm{Hg}$ is desorbed from the sample trap it is carried by the $\mathrm{Ar}$ carrier gas at a flow of $20 \mathrm{~mL} / \mathrm{min}$ into the $\mathrm{GC}$ column where the elemental $\mathrm{Hg}$, methylethyl $\mathrm{Hg}$ and the diethyl $\mathrm{Hg}$ are separated. Following separation, the individual $\mathrm{Hg}$ species are carried into the pyrolytic column where the methylethyl and diethyl $\mathrm{Hg}$ species are reduced thermally to elemental $\mathrm{Hg}$.

G. The CVAFS detector can only detect elemental mercury. The detector then outputs a millivolt signal to the integrator resulting in three distinct peaks (fig. 4). 


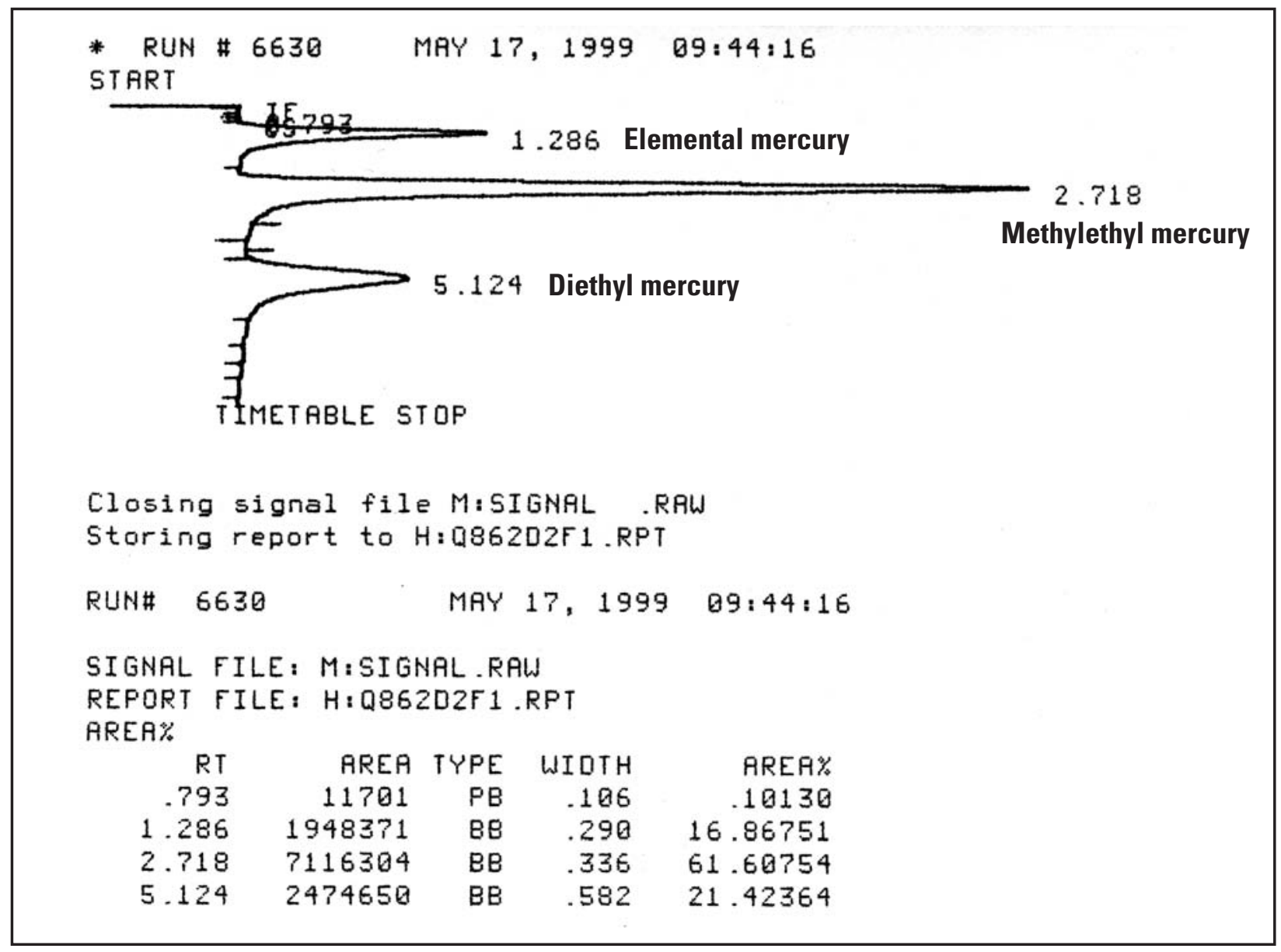

Figure 4. Example of methyl mercury detection chromatograph with peak identities.

H. After the standard curve and the ethylation blanks have been analyzed, and found to meet the daily quality objectives (DQO), the distillates from the batch can be analyzed. The procedure for analyzing the method blanks, environmental samples, matrix spikes and matrix-spike duplicates are identical to the procedure used for the standards and ethylation blanks. Simply dispense an appropriate amount of distillate into the reaction vessel, add the acetate buffer and the $\mathrm{NaBEt}_{4}$ and proceed as in step $\mathrm{B}$. An appropriate amount of sample would be an amount that produces a $\mathrm{CH}_{3} \mathrm{Hg}^{+}$peak with an area that falls within the calibration range (for most water samples this amount is the entire distillate volume).

\section{Data Interpretation}

The integrator output should show three distinct peaks for a given sample (fig. 4). A peak for the elemental $\mathrm{Hg}$ appears at approximately 1 minute and 30 seconds, the methylethyl $\mathrm{Hg}$ peak at 2 minutes and 40 seconds, and the diethyl $\mathrm{Hg}$ peak appears at 4 minutes and 40 seconds. The methylethyl $\mathrm{Hg}$ peak is the peak of interest and the area under its curve is used to calculate concentration of $\mathrm{CH}_{3} \mathrm{Hg}^{+}$in the original sample.

Peak areas obtained for the standards during the calibration are corrected for $\mathrm{CH}_{3} \mathrm{Hg}^{+}$in the acetate buffer and the $\mathrm{NaBEt}_{4}$ by subtracting the average peak area of the ethylation blanks (DQO is absolute mass less than or equal to $2 \mathrm{pg}$ ). Simple linear regression, forcing zero intercept, is applied to the peak area/mass combinations to determine the best-fit line (DQO is a correlation coefficient equal to or greater than 0.995) and establish the equation used to determine the mass of the sample aliquot from its resulting peak area. Each distillation batch contains three method blanks (DQO is an absolute mass less than or equal to $5 \mathrm{pg}$ ) to evaluate the contribution of $\mathrm{CH}_{3} \mathrm{Hg}^{+}$from the distillation process and reagents. The average mass found in these blanks is subtracted from the mass in the sample dis- 
tillates. After correcting for the method blanks, the final sample concentrations are corrected for the fraction distilled (because the fraction of methyl mercury distilled is equal to the fraction of the sample volume distilled), and the difference between the volume of the distillate ethylated and the total volume of distillate recovered. The following series of formulas are used to calculate final concentration.

SAMPLE VOLUME:

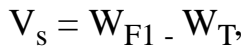

where

$\mathrm{V}_{\mathrm{s}}=$ sample volume

$\mathrm{W}_{\mathrm{F} 1}=$ weight of reaction vessel with sample

$\mathrm{W}_{\mathrm{T}}=$ weight of reaction vessel

FRACTION DISTILLED:

$\mathrm{D}=\mathrm{V}_{\mathrm{S}} /\left(\mathrm{W}_{\mathrm{F} 2}-\mathrm{W}_{\mathrm{W}}\right)$,

where

$\mathrm{D}=$ fraction distilled

$\mathrm{V}_{\mathrm{S}}=$ sample volume

$\mathrm{W}_{\mathrm{F} 2}=$ weight of receiving vessel after distillation

$\mathrm{W}_{\mathrm{W}}=$ weight of receiving vessel with reagent water before distillation

MASS OF Hg IN ALIQUOT ANALYZED

$\mathrm{M}_{\mathrm{A}}=(\mathrm{PA} / \mathrm{S})-\mathrm{MB}_{\mathrm{AVE}}$,

where

$\mathrm{M}_{\mathrm{A}}=$ mass per aliquot

$\mathrm{PA}=$ peak area

$\mathrm{S}=$ slope of calibration line

$\mathrm{MB}_{\mathrm{AVE}}=$ average mass found in method blanks

MASS OF Hg IN ORIGINAL SAMPLE

$\mathrm{M}_{\mathrm{S}}=\left(\mathrm{M}_{\mathrm{A}} / \mathrm{D}\right) *\left(\left(\mathrm{~W}_{\mathrm{F} 2}-\mathrm{W}_{\mathrm{T} 2}\right) /\left(\mathrm{W}_{\mathrm{F} 2}-\mathrm{W}_{\mathrm{A}}\right)\right)$,

where

$\mathrm{M}_{\mathrm{S}}=$ mass in original sample

$\mathrm{M}_{\mathrm{A}}=$ mass per aliquot

$\mathrm{D}=$ fraction distilled

$\mathrm{W}_{\mathrm{F} 2}=$ weight of receiving vessel after distillation

$\mathrm{W}_{\mathrm{T} 2}=$ weight of receiving vessel

$\mathrm{W}_{\mathrm{A}}=$ weight of receiving vessel after pouring off aliquot to be ethylated

FINAL $\mathrm{CH}_{3} \mathrm{Hg}^{+} \mathrm{CONCENTRATION}$

$\mathrm{C}=\mathrm{M}_{\mathrm{S}} / \mathrm{V}_{\mathrm{S}}$,

where

$\mathrm{C}=$ concentration

$\mathrm{M}_{\mathrm{S}}=$ mass in original sample

$\mathrm{V}_{\mathrm{S}}=$ sample volume 
Table 2a. Results for the analysis of ground water spiked at two different concentrations [All concentrations in nanograms per liter (ng/L)]

\begin{tabular}{lcccr}
\hline & $\begin{array}{c}\text { Ground water spiked at } \\
\mathbf{0 . 1} \mathbf{~ n g / L}\end{array}$ & Percent recovery & $\begin{array}{c}\text { Ground water spiked at } \\
\mathbf{1 . 0} \mathbf{~ n g / L}\end{array}$ & Percent recovery \\
\hline 0.093 & 95.2 & 0.927 & 92.6 \\
.078 & 79.9 & 1.15 & 114.3 \\
.095 & 97.6 & .933 & 93.1 \\
& .090 & 91.6 & .835 & 83.4 \\
& .064 & 62.2 & .886 & 108.6 \\
& .090 & 91.8 & 1.088 & 99.4 \\
& .099 & 101.6 & .995 & 84.2 \\
\hline Average & .085 & 87.0 & .843 & 95.5 \\
Standard deviation & .087 & 88.8 & .956 & 95.5 \\
Percent relative & .087 & 88.8 & .956 & 11.21 \\
standard deviation & .011 & 11.5 & .112 & 11.7 \\
\hline
\end{tabular}

\section{METHOD PERFORMANCE}

Precision and accuracy for this method were evaluated using three water sources at two concentrations and analyzed seven times each (U.S. Geological Survey, Office of Water Quality Technical Memorandum 98.05) over a period of five days using different calibration curves. Memorandum 98.05 recommends the use of surface water, ground water, and reagent water as the three sources; however, multiple analyses of reagent water spiked with $\mathrm{CH}_{3} \mathrm{Hg}^{+}$resulted in consistently poor recoveries of $\mathrm{CH}_{3} \mathrm{Hg}^{+}$for undetermined reasons and, thus, reagent water was not used to evaluate this method. Instead, ground water from a residential well, surface water from a freshwater lake in Canada, and surface water from the Everglades in southern Florida were used to evaluate method performance. The ground water was found to contain no $\mathrm{CH}_{3} \mathrm{Hg}^{+}$on initial analysis; therefore, analyte was spiked into this matrix so that it could be evaluated for precision and accuracy. Both surface-water samples contained $\mathrm{CH}_{3} \mathrm{Hg}^{+}$at detectable (greater than $0.04 \mathrm{ng} / \mathrm{L}$ ) concentrations. The USGS requires that sample matrices be evaluated at two different concentrations; therefore, the ground-water sample was spiked at two different concentrations and the surface-water samples were spiked with analyte so that two different concentrations could be evaluated. The results of the analyses of these matrices are presented in tables $2 \mathrm{a}-\mathrm{c}$.
Method precision was evaluated by examining the percent relative standard deviation of the concentrations obtained from all analyses of each matrix at each concentration. The percent relative standard deviations ranged from 10.2 to 15.6. Average recoveries of the added analyte obtained at the different concentrations in the different matrices evaluated ranged from 88.8 to 117 percent, which are considered within acceptable method performance limits for accuracy at laboratories using this analytical method (Nicolas Bloom, Frontier Geosciences, Seattle, Washington, written communication, 1999).

\section{SUMMARY AND CONCLUSIONS}

This report documents a method for the analysis of $\mathrm{CH}_{3} \mathrm{Hg}^{+}$in water samples, and describes the results of a methodological test of the WDML's ability to provide quality $\mathrm{CH}_{3} \mathrm{Hg}^{+}$data at $\mathrm{ng} / \mathrm{L}$ concentrations. Acceptance of this method by the USGS will help to establish a National database of $\mathrm{CH}_{3} \mathrm{Hg}^{+}$concentrations from areas across the nation. The need for a reliable method of $\mathrm{CH}_{3} \mathrm{Hg}^{+}$detection was precipitated by the National Water-Quality Assessment program's identification of mercury as one of the top five priority issues over the next 10 years coupled with the fact that $\mathrm{CH}_{3} \mathrm{Hg}^{+}$is the species of mercury that most readily bioaccumulates in mammals.

The Wisconsin District Mercury Laboratory has adapted a distillation/ethylation/gas-phase separation 
Table 2b. Results for the analysis of spiked and unspiked Canada surface water. [All concentrations in nanograms per liter (ng/L); --, no sample]

\begin{tabular}{|c|c|c|c|}
\hline & Surface water unspiked & $\begin{array}{c}\text { Surface water spiked at } \\
0.627 \mathrm{ng} / \mathrm{L}^{1}\end{array}$ & Percent recovery \\
\hline & 0.134 & 0.638 & 101.8 \\
\hline & .095 & .571 & 91.0 \\
\hline & .123 & .606 & 96.6 \\
\hline & .102 & .668 & 106.6 \\
\hline & .101 & .573 & 91.4 \\
\hline & .116 & .564 & 89.9 \\
\hline & .115 & .482 & 76.9 \\
\hline & .095 & -- & -- \\
\hline Average & .110 & .586 & 93.5 \\
\hline Standard deviation & .014 & .060 & 9.57 \\
\hline $\begin{array}{l}\text { Percent relative } \\
\text { standard deviation }\end{array}$ & 12.9 & 10.2 & 10.2 \\
\hline
\end{tabular}

${ }^{1}$ Concentration calculated by adding average concentration of sample to known spike addition

Table 2c. Results for the analysis of spiked and unspiked Everglades' surface water [all concentrations in nanograms per liter (ng/L)]

\begin{tabular}{lccc}
\hline & $\begin{array}{c}\text { Everglades water } \\
\text { unspiked }\end{array}$ & $\begin{array}{c}\text { Everglades water } \\
\text { spiked at 1.25 } \mathbf{~ n g} / \mathbf{L}^{\mathbf{1}}\end{array}$ & Percent recovery \\
\hline 0.255 & 1.51 & 120.8 \\
.300 & 1.63 & 130.1 \\
.236 & 1.02 & 81.6 \\
.280 & 1.48 & 118.2 \\
& .275 & 1.47 & 118.0 \\
& .323 & 1.64 & 131.2 \\
\hline Average & .278 & 1.46 & 116.6 \\
Standard deviation & .031 & 0.227 & 18.2 \\
Percent relative & 11.1 & & 15.6 \\
standard deviation & & 15.6 & \\
\hline
\end{tabular}

\footnotetext{
${ }^{1}$ Concentration calculated by adding average concentration of sample to known spike addition.
} 
method with cold vapor atomic fluorescence spectroscopy detection for the determination of methyl mercury in filtered and unfiltered waters. A method detection limit of $0.04 \mathrm{ng} / \mathrm{L}$ was proven to be achievable from multiple matrices using this method. The accuracy of this method also was tested using multiple matrices at different concentrations and found to be acceptable based on average spike recoveries ranging from 88.8 to 117 percent.

Reagent water is not an appropriate matrix to evaluate method performance as spiked reagent water consistently results in low recovery. Low ionic strength water samples such as snow have also resulted in low recoveries at the WDML as well as other laboratories using this method. Samples high in dissolved organic carbon (DOC) also can be difficult to evaluate because the spike recoveries can be quite inconsistent. When analyzing these types of water samples with these matrices, professional judgment and caution must be used in evaluating method performance.

\section{REFERENCES}

Bloom, N.S., 1992, On the methylmercury content of fish: Canadian Journal of Fisheries and Aquatic Sciences, v. 49, p. 1131-1140.

1995, Ultraclean sampling and handling: Environmental Laboratory, March/April, p. 20-25.

Brumbaugh, W.G., Krabbenhoft, D.P., Helsel, D.R., Weiner, J.G., and Echols, K.R., 2001, A national pilot study of mercury contamination of aquatic ecosystems along multiple gradients-bioaccumulation in fish: USGS/BRD/BSR-2001-0009, 25 p.

Horvat, M., Liang, L., and Bloom, N.S., 1993, Comparison of distillation with other current isolation methods for the determination of methyl mercury compounds in low level environmental samples, part II-water: Analytica Chimica Acta, v. 282, p. 153-168.
Krabbenhoft, D.P., Olson, M.L., Dewild, J.F., Clow, D.W., Striegl, R.S., Dornblaser, M.M., and VanMetre, Peter, in press, Mercury loading and methylmercury production and cycling in high-altitude lakes from the Western United States: Biogeochemistry.

Krabbenhoft, D.P., Wiener, J.G., Brumbaugh, W.G., Olson, M.L., DeWild, J.F., and Sabin, T. J., A national pilot study of mercury contamination of aquatic ecosystems along multiple gradients, in Morganwalp, D.W., and Buxton, H.T., eds., U.S. Geological Survey Toxic Substances Hydrology Program, proceedings of the technical meeting, Charleston, S.C., March 8-12, 1999: U.S. Geological Survey Water-Resources Investigations Report 99-4018-B, p. 147-160.

Olson, M.L., Cleckner, L.B., King, S.A., Hurley, J.P., and Krabbenhoft, D.P., 1997, Resolution of matrix effects on analysis of total and methyl mercury in aqueous samples from the Florida Everglades: Fresenius Journal of Analytical Chemistry, v. 358, p. 392-396.

U.S. Environmental Protection Agency, 1990, Guidelines establishing test procedures for the analysis of pollutants (Appendix B, Part 136, Definition of procedures for the determination of the method detection limit-Revision 1.11): Revised as of July 1, 1999, p. 537-539.

2001a, Fact sheet update-National Listing of Fish and Wildlife Advisories: Washington, D.C., Office of Water, EPA-823-F-01-010, 6 p.

2001b, Water quality criterion for the protection of human health-methyl mercury: Washington, D.C., Office of Science and Technology, Office of Water, EPA-823-R-01-001, p. 7-1

U.S. Geological Survey, 1998, Policy for the approval of U.S. Geological Survey water-quality analytical methods: Office of Water Quality Technical Memorandum 98.05, [http://water.usgs.gov/admin/memo/QW/ qw98.05.html] 